\title{
Empirical Analysis for the Factors Affecting the Adoption of Cloud Computing Initiatives by Information Technology Executives
}

\author{
Mohammad AbdulQadir Obeidat \\ University of Jordan, Jordan \\ E-mail: mobeidat@bus.illinois.edu \\ Prof. Dr. Tayfun Turgay \\ Girne American University, Cyprus \\ E-mail: tayfunturgay@gau.edu.tr
}

Received: Nov. 26, 2012

Accepted: December 20, 2012 Published: January 1, 2013

doi:10.5296/jmr.v5i1.2764

URL: http://dx.doi.org/10.5296/jmr.v5i1.2764

\begin{abstract}
The tremendous explosion of technology acceptance theories has not spared the corpus of technology adoption literature from criticism that most of these models only evaluate the adoption of new technology from a single perspective. In an effort to attenuate this criticism, this breaks ranks with extant theories and proposes a unified model for evaluating technology adoption from multiple perspectives. The Technology Trade Theory (Triple-T) model which this study proposes integrates the Social Exchange Theory into the Technology Acceptance Model, and proposes that technology acceptance is a function of a deliberate process of weighing the advantages associated with that technology against its disadvantages. Adoption only happens when the advantages outweigh the disadvantages; otherwise, prospective adopters reject the technology. In this, the model recognizes a total of eight advantages and eight disadvantages associated with cloud computing, on the basis of which its claims are validated.

Data is collected by means of structured psychometric scales administered to a panel of medium and top level IT managers. Psychometric scales are also used to attach weights to each of the variables under study. The Pearson's coefficient and paired tailed tests are used to analyze the nature, strength and significance of the findings. Findings validate the major claims of the study, on the basis of which research implications are extensively discussed.
\end{abstract}


Keywords: Cloud computing, Triple-T, Technology acceptance, Integrative technology adoption model, Social exchange theory. 


\section{Introduction}

Cloud computing is one of the emerging areas in the field of information science and has been billed as a hot-growth area based on its potential benefits. Though the adoption of cloud computing has been growing, its rate of acceptance even in developed countries remains fairly low at about 37\% (McKendrick, 2011). It is against this background that this study undertakes an assessment of cloud computing adoption.

Scholars and practitioners have researched and are still analyzing the factors that influence technology acceptance. Theories and models developed by scholars in this field have tended to focus on the factors that influence technology acceptance and have rarely weighed them. Most studies have tended to gauge the effect of each single variable rather than weighing and modeling it systematically. Technology Trade Theory (Triple-T or T3), the unified theoretical framework which this study proposes, is a comprehensive and more powerful in describing and predicting consumer adoption of technology and therefore goes a long way in bridging this gap.

\section{Problem Statement}

The technology acceptance model (TAM) is the most commonly used model for explaining technology adoption behavior, this notwithstanding the fact that it has been associated with fundamental weaknesses which blunt its robustness and predictive ability. Technological advances such as autonomic computing and virtualization have led to the emergence of cloud computing which promises significant benefits for businesses which adopt this technology, necessitating the need for a better way for understanding the technological adoption process in order to ensure that business organizations reap the benefits associated with cloud computing.

Although the emergence of cloud computing has attracted enormous interest in, very few studies have attempted to explain the acceptance of this technology using technology adoption models. Moreover, that previous technology adoption models evaluate the adoption process from a single perspective (Chuttur, 2009) necessitates the need for the adoption of cloud computing to be evaluated using a model in which multiplicity of perspectives is embedded, hence Triple-T model is proposed.

\section{Significance of Research}

The formulation and validation of the proposed Triple-T model offers an alternative to the earlier models, and its promise of a higher predictive ability assures of a remedy to the weaknesses extant in previous technology adoption models. As such, this study presents a more robust and multifaceted model for the evaluation of technology acceptance, paving the way for a fuller and richer understanding of technology acceptance. Moreover, based on the findings made, the conclusions drawn are likely to help business organizations and policymakers to improve efficiencies, reduce costs, and formulate more appropriate policies.

\section{Research Objectives}

The objectives of this study include: 
1. To incorporate the Social Exchange Theory into the Technology Acceptance Model with a view of formulating and validating a unified theory that can be used to evaluate technology adoption, with specific reference to cloud computing

2. To validate the relationships among the various variables in the TAM framework

3. To improve the conceptualization of perception by identifying and categorizing all technology related features into two main categories advantages and disadvantages.

4. To evaluate whether the advantages of cloud computing initiatives outweigh its disadvantages

\section{Research Questions}

The main research questions for the study are:

1. What are the advantages and disadvantages of cloud computing?

2. Do the advantages of cloud computing outweigh its disadvantages?

\section{Research Hypothesis}

The research hypothesis is given as:

- $\mathrm{H} 1_{\mathrm{A}}$ : the advantages of cloud computing initiatives outweigh its disadvantages

- $\mathrm{H} 1_{0}$ : the advantages of cloud computing initiatives do not outweigh its disadvantages

\section{The Proposed Model}

To evaluate the adoption of cloud computing technology, this study will use the Technology Trade Theory (Triple-T) model, which is the product of the integration of two models: the social exchange theory and the technology acceptance model. This model can be illustrated by means of a diagram, as shown in Figure 1 below: 


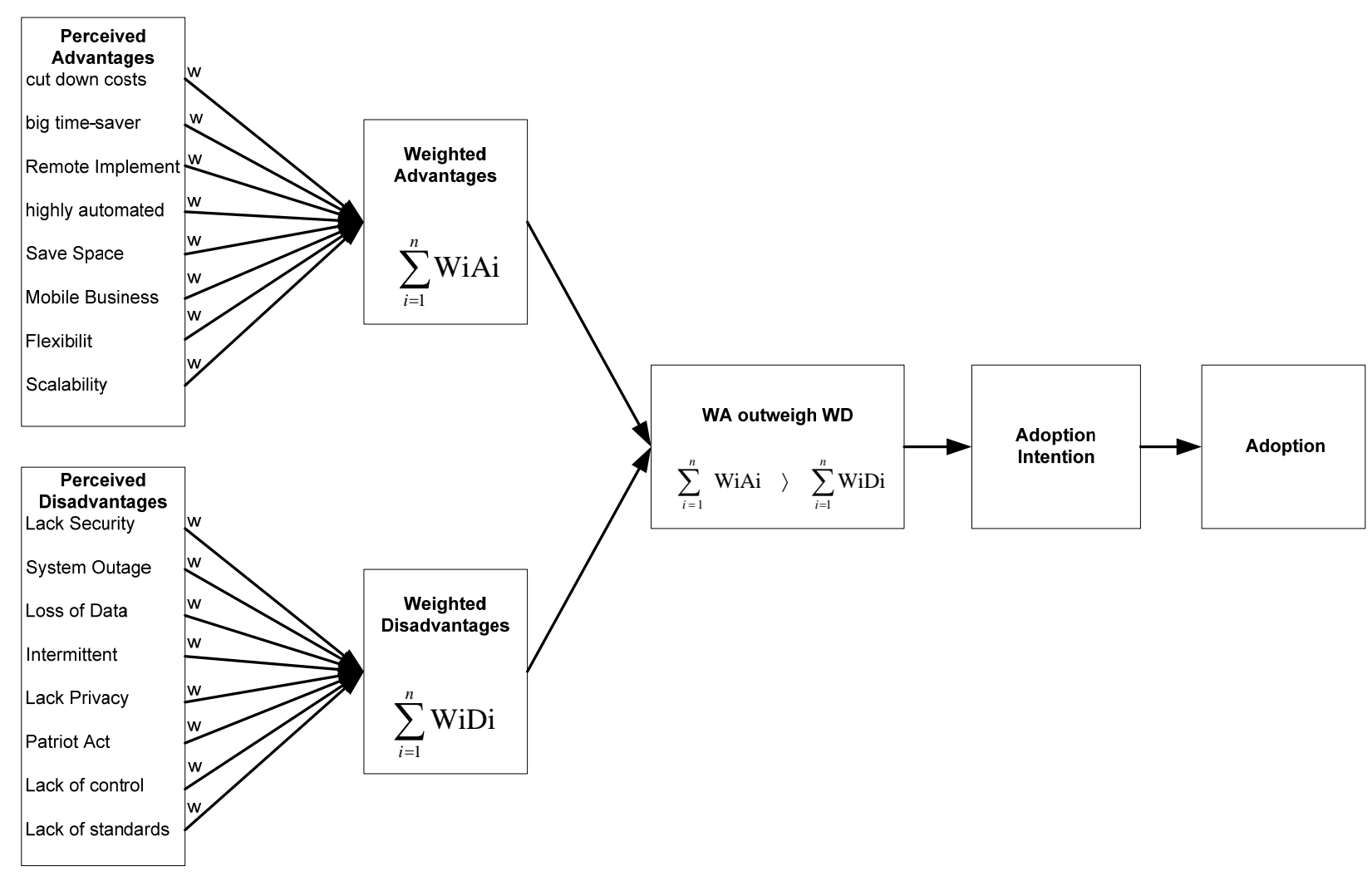

TECHNOLOGY TRADE THEORY (Triple-T)

Figure 1. The Proposed Triple-T Model

Technology Trade Theory (Triple-T) has posited that an individual's adoption intentions are a function of the outweighed advantages. This relationship can also be expressed mathematically as shown in the following equation:

$$
\mathrm{AI}=\sum_{\mathrm{i}=1}^{\mathrm{n}} \mathrm{WiAi}-\sum_{\mathrm{i}=1}^{\mathrm{n}} \mathrm{WiDi}(7.1)
$$

Where: AI refers to the Adoption Intention; individual's intention to carry out adoption A, Wi refers to the weight assigned to each advantage and/or disadvantage using 9-point Likert scale, Ai refers to the score assigned to each advantage using 5-point Likert scale, Di refers to the score assigned to each disadvantage using 5-point Likert scale and $\mathrm{n}$ represents the number of the potential advantages and/or disadvantages of technology.

Based on the identified advantages, disadvantages, and features of cloud computing as presented in the literature review section, the proposed Triple-T model incorporates a total of sixteen variables. These include a set of eight advantages and a set of eight disadvantages. The advantages include: cost savings, time savings, high automation, space savings, scalability, flexibility, remote implementation and business mobility. On the other hand, the 
disadvantages include: loss of control, lack of standards, lack of privacy, loss of data, intermittency, system outages, the Patriot Act, and lack of privacy.

\section{Methodology and Research Design}

The research adopted the panel study method. Respondents included thirty middle and top level executives who either had functional IT roles or were likely to be affected by cloud computing adoption. The simple random sampling method was used to select the respondents. The profile of the sampled respondents is presented in table 1 :

Table 1. Profile of the Sampled Respondents

\begin{tabular}{|c|c|c|c|c|c|}
\hline Title & Number & Company & Experience & Age & Mandatory \\
\hline $\mathrm{CIO}$ & 3 & $\begin{array}{l}\text { Digital Chocolate, Voxer, and } \\
\text { ModCloth }\end{array}$ & $\begin{array}{l}\text { Varied, } \\
\text { between } 1 \text { and } \\
10 \text { years }\end{array}$ & $\begin{array}{l}\text { Varied, } \\
\text { between } 24 \\
\text { and } 40 \text { years }\end{array}$ & All voluntary \\
\hline $\begin{array}{l}\text { CTO, COO, } \\
\text { and ranking } \\
\text { IT staff }\end{array}$ & 10 & BT, and Equity Bank & $\begin{array}{l}\text { Varied, } \\
\text { between } 1 \text { and } \\
15 \text { years }\end{array}$ & $\begin{array}{l}\text { Varied, } \\
\text { between } 29 \\
\text { and } 60\end{array}$ & $\begin{array}{l}\text { Seven voluntary, } \\
\text { three mandatory }\end{array}$ \\
\hline $\mathrm{COO}$ & 10 & $\begin{array}{l}\text { Avago, Eyetrix Media, Dolby, } \\
\text { Genentech, DeNovo Inc, } \\
\text { Japan Post, Previder, } \\
\text { Qualcomm, Starbucks, and } \\
\text { LinkedIn }\end{array}$ & $\begin{array}{l}\text { Varied, } \\
\text { between } 5 \text { and } \\
25 \text { years }\end{array}$ & $\begin{array}{l}\text { Varied, } \\
\text { between } 29 \\
\text { and } 60\end{array}$ & All voluntary \\
\hline $\begin{array}{l}\text { Chief } \\
\text { Security } \\
\text { Officer }\end{array}$ & 1 & Angus Genomics & 8 years & 33 & Voluntary \\
\hline $\begin{array}{l}\text { Ranking IT } \\
\text { officers }\end{array}$ & 6 & Assorted US Federal agencies & $\begin{array}{l}\text { Varied, } \\
\text { between } 5 \text { and } \\
25 \text { years }\end{array}$ & $\begin{array}{l}\text { Varied, } \\
\text { between } 29 \\
\text { and } 60\end{array}$ & $\begin{array}{l}\text { Mandatory (due } \\
\text { to “cloud first" } \\
\text { policy }\end{array}$ \\
\hline
\end{tabular}

\section{Instrumentation}

Data was collected using structured survey questionnaires administered over the internet. Five-point Likert scales were used to evaluate the strength of the responses. Weighting of the advantages and disadvantages was based on a nine-point scale running from 0.1 to 0.9 . The various advantages and disadvantages were adopted as the independent variables. Adoption intentions and actual adoption were adopted as the dependent variables. For the relationship between adoption intentions and actual adoption, the former was taken as the independent variable and the latter as the dependent variable. 


\section{Statistical Methods Used in Hypothesis Testing}

Given the ordinal nature of the data collected, the relationships between the various variables were assessed using the Pearson correlation coefficient. Significance was tested using paired tailed tests and the t-statistic. The rival hypothesis was affirmed only when the value of weighted disadvantages exceeded that of weighted advantages. Data quality was tested using Cronbach's alpha.

\section{Previous Studies}

\section{Empirical Research in Cloud Computing Technology}

Cloud computing has formally been defined as "a model for enabling convenient, on-demand network access to a shared pool of configurable computing resources (e.g., networks, servers, storage, applications, and services) that can be rapidly provisioned and released with minimal management effort or service provider interaction” (Mell \& Grance, 2009, p. 1).

It is based on multiple technologies, which include: "web services, virtualization, the internet, service-oriented architecture, autonomic system computing, multi-tenancy, web application frameworks, open source software, and grid computing” (Shimba, 2010, p.9; Jlelaty \& Monzer, 2012, p.11).

Cloud computing characteristics have been classified into essential and common characteristics (Plummer et al, 2009; Grance, 2010), as shown in Table 2 below:

Table 2. Characteristics of Cloud Computing

\begin{tabular}{|l|l|}
\hline Essential characteristics & Common characteristics \\
\hline On-demand self-service & Use of a pay as you go model \\
\hline Broad network access & Use of virtualized technology \\
\hline Rapid elasticity & Geographical spread of clouds \\
\hline Measurability & Homogeneity \\
\hline Resource pooling & Resilient computing \\
\hline & Immense storage and computing scale availability \\
\hline & Reduced upfront investment costs \\
\hline & Reduced running and overhead costs \\
\hline
\end{tabular}

Source: Shimba (2010, p.14), Mell \& Grance (2009, p.1)

The three models of cloud computing services include: Software-as-a-Service (SaaS), Platform-as-a-Service (PaaS), and Infrastructure-as-a-Service (IaaS) (Ahronovitz et al, 2010; Mell \& Grance, 2009). In the SaaS model, clients may only access services from the service provider, but have no control over cloud applications or infrastructure. In the PaaS model, users may - in addition to the services - have control over the applications but have no control 
over the infrastructure. In the IaaS model, the users have control over the operating systems, storage, network modules, and applications (Mell \& Grance, 2009; Shimba, 2010).

Ahronovitz et al (2010) identify four types of deployment models: hybrid, public, community, and private clouds. In the public cloud, services are shared, low cost or free, negotiated using SLA's, paid for on a pay-as-you-go model, and users may be allowed to control who can access their data (Jlelaty \& Monzer, 2012; Shimba, 2010). In the private cloud resources are not shared but public access is restricted, they are sited in-house, and users have control over the infrastructure. Private clouds are costly but give users more bandwidth (Jlelaty \& Monzer, 2012; Shimba, 2010). The hybrid cloud combines two or more cloud types (e.g. private and public clouds), each of the clouds maintains its unique identity, and the various clouds are connected using common or proprietary technology (Jlelaty \& Monzer, 2012). In the community cloud, ownership of the cloud infrastructure is vested in a number of clients who share common interests. Such infrastructure may be sited in-house or off-site, and may be run by them or by third parties, and the various clients or organizations enjoy shared access to the resources (Shimba, 2010).

The cloud computing architecture is composed of two sections, the front end and the back end. The former is the client end, and the latter is the service provider end. These two communicate with each other through internet-enabled networks. The front end typically consists of the client's computer and will contain the applications used by the client to access the cloud system, services, or resources. The back end typically comprises of the various hardware devices required to run the system, including storage devices, servers, and computers. The back end also includes the operating software and application software used to run the system. Each of the applications in the back end will have a dedicated server, with the cloud computing system being administered through a central server which monitors all the incoming and outgoing traffic, and ensures that all operations are accomplished with minimal or no problems. The server's operations run on middleware, they are guided by predetermined protocols, can be virtualized to optimize performance and reduce the need for more physical machines. Data backup is undertaken to prevent data losses in case of a system crash. The operation of the cloud computing system is illustrated in Figure 2 below: 


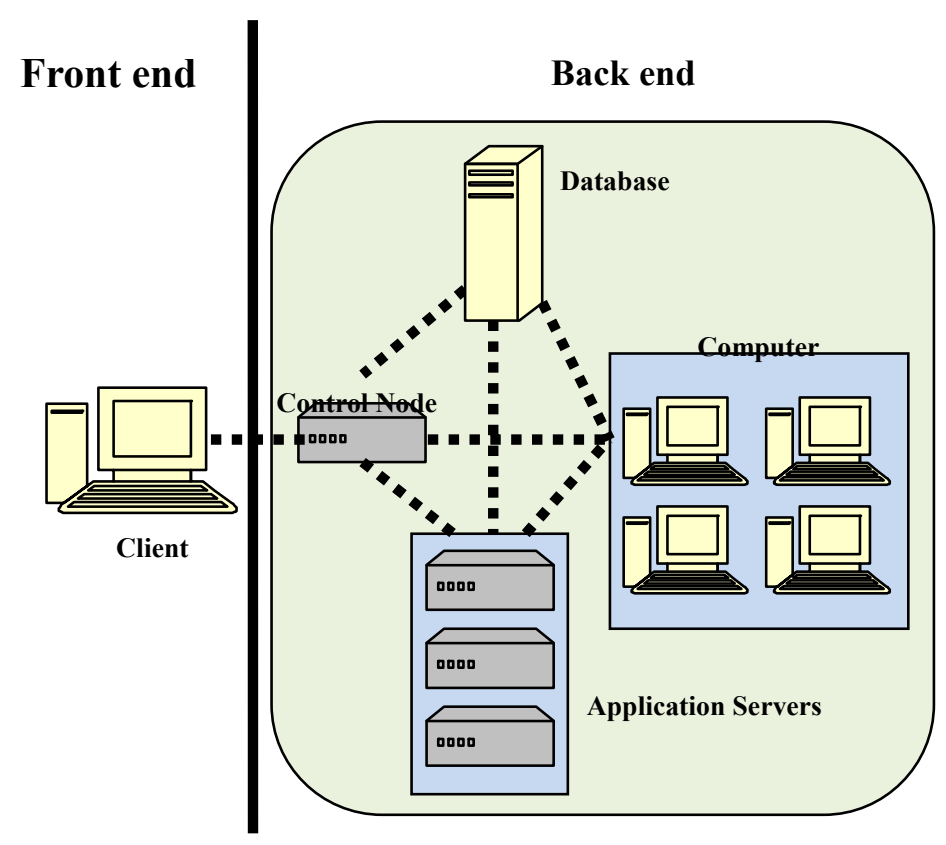

Figure 2. How cloud computing works

Cloud computing applications have been deployed in many areas, including word processing, social media, project management, e-mail, contact management, wikis, web development, payroll management systems, online chatting, discussion groups, customer relationship management, time-management, data storage, accounting, presentations, file hosting, and note taking. Some examples of these applications include: Google Apps (e.g. Google Docs), BaseCamp, High rise, Campfire, Ever note, Zero, Pay Cycle, WorkFlowMax, Log Mein, and Carbonite.

Cloud computing has many advantages. Since it facilitates resource sharing, cloud computing creates scale economies leading to significant cost savings for users (Shimba, 2010). The users are freed from the need to undertake large and costly upfront investment in IT infrastructure, or to maintain a large IT workforce since such operations are outsourced to service providers (Marston et al, 2011; Voona and Venkantaratna, 2009, Buyya et al., 2008). Outsourcing also frees personnel to focus less on mundane activities and more on value-adding activities. (Marston et al, 2011). Cloud computing allows firms to scale down or upgrade their resource use as the market or industry conditions shift, and thus endows organizations with a "high degree of strategic flexibility" (Jlelalty \& Monzer, 2012, p.16; Marston et al., 2011). It increases to-market speed, facilitates space and time savings, remote implementation, mobile business, and is more user-friendly compared to grid systems (Jlelalty \& Monzer, 2012). Space savings result from lower physical space requirements since the adoption of cloud computing translates to less floor space or fewer racks to accommodate machines, servers, and other hardware) (Behrend et al, 2011). Since it allows or automation of tasks, tasks are also completed faster leading to time savings. The users are also able to access resources from a geographically dispersed location, which should result into reduced 
hardware requirements, better costs, and lower maintenance demands; and to transact business on the go (Behrend et al, 2011).

Cloud computing has several disadvantages, including: enhanced security risks, high risks of data loss, and service downtimes (Miller, 2008; Jeffrey \& Neidecker-Lutz, 2009), loss of control, intermittency, privacy infringement, inflexibility due to a high lock-in potential, slow internet speeds, and legislative bottlenecks (Géczy, Izumi, \& Hasida, 2011). The lack of common interfaces and protocols in the delivery of cloud computing, results into lack of interoperability between clouds, raising lack of trust, and customer lock-in, among many other effects, thus raising barriers to the adoption of cloud computing (Sriram \& Khajeh-Hosseini, 2010). Cost savings may arise from the low maintenance costs, low personnel requirements, low energy consumption, or low investment in hardware and software required as a result of adopting cloud computing (Shimba, 2010). Adopters of cloud computing are also likely to be exposed to high vulnerability of security risks (e.g. DDoS attacks) or to lose their data or privacy due to the multi-tenancy aspect of cloud computing (Shimba, 2010). Moreover, system unavailability occasioned by technical glitches from the back ends, power outages, and internet downtimes, or any such factors; is another cloud computing disadvantage (Shimba, 2010). Cloud computing involves outsourcing of an organization's resources to third party providers. This eliminates the direct control which the adopter has over his resources, and potentially creates elevated vulnerability to risks such as security risks, data loss, and privacy infringement. It may also lead to unforeseen costs or inconveniences arising from the erratic, alternating, or unpredictable supply of computational resources by the service provider (Jlelalty \& Moner, 2012). Moreover, cloud computing adoption may subject the users to inconveniences posed by legal enactments such as the Patriot Act, which may reduce the individual's intentions to adopt cloud computing Géczy, Izumi, and Hasida (2011).

\section{Gaps in the Literature of Cloud Computing Technology}

Research studies on cloud computing remain relatively few (Jaatmaa, 2010; Sriram \& Khajeh-Hosseini, 2010). Not only are they are few, but they also focus on just two general areas: the effects of the adoption of cloud computing at the firm level, and the technical considerations involved in the implementation of cloud computing at the firm level (Sriram \& Khajeh-Hosseini, 2010). To the best of the researcher's knowledge, few or no the studies focusing on the behavioral characteristics of cloud computing adoption, and specifically those using the technology adoption theories as the basic grounding, exist and this is the gap which the study aims to fill.

\section{Empirical Research in Relevant Disciplines: Theories of Technology Adoption}

The main technology acceptance theories include the Technology Acceptance Model (TAM) and TAM 2, the Social Exchange Theory (SET), the Theory of Planned Behavior (TPB), the Theory of Reasoned Action (TRA), the Decomposed Theory of Planned Behavior, Motivational Model, the Model of PC Utilization, the Innovation Diffusion Theory, the Unified Theory of Acceptance and Use of Technology (UTAUT) and the Social Exchange Theory (SET) (Chuttur, 2009). The Theory of Reasoned Action was formulated by Fishbein 
\& Ajzen (1980) and posits that behavioral intentions are influenced by attitudes and subjective norms. The behavioral intentions ultimately lead to the actual behavior.

The Theory of Planned Behavior (TPB) improves on the TRA by integrating the "perceived behavioral control" (or PBC) variable into the TRA. PBC refers to how difficult or easy the individual perceives the performance of a given behavior to be, and is a function of the available opportunities and resources required to perform that action and of control factors (Hale, Householder, \& Greene, 2003). The integration of the PBC into the TRA allows the TPB to address the TRA's inability to account for non-controllable variables affecting behavior, but its mere aggregation of these variables without any attempt to identify them has been criticized due to its propensity to introduce bias (Taylor \& Todd, 1995; Al-Qeisi, 2009).

The Technology Acceptance Model (TAM) was formulated by Fred Davis (1986) and is based on the stimulus-response model (Chuttur, 2009). TAM builds on the TRA, and proposes that behavioral intentions are influenced by two variables, which themselves are shaped by the technology's features and capabilities: perceived ease of use and perceived usefulness. Behavioral intentions in turn drive the actual behavior. Later, external variables were integrated into the model. The refined TAM model is illustrated in Figure 5:

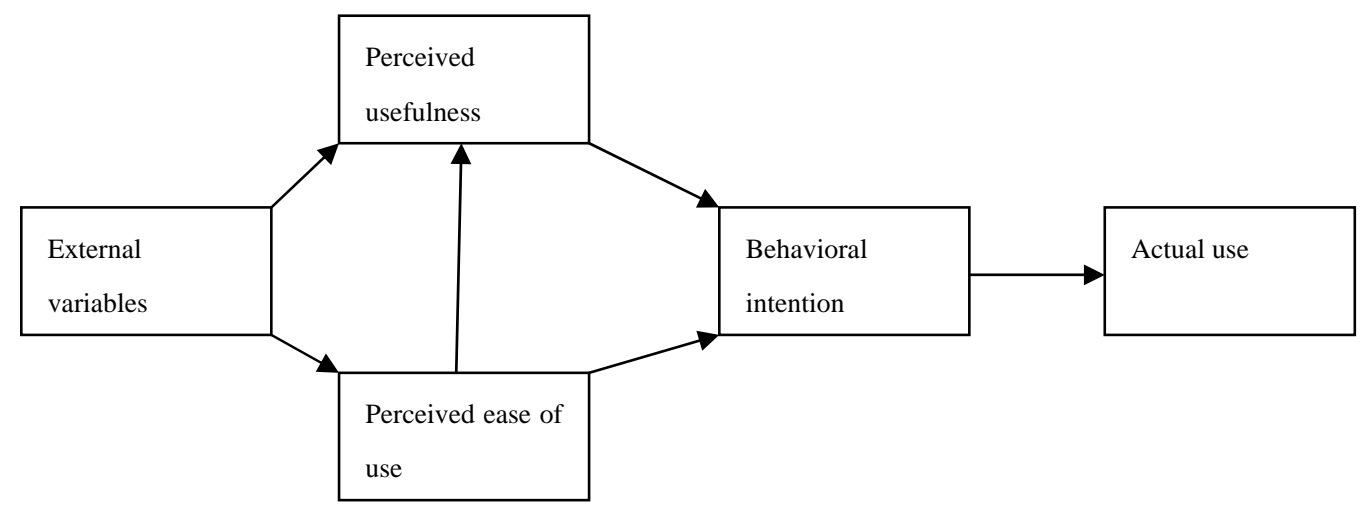

Figure 3. The TAM Model. Source: Venkatesh \& Davis, 1996, p.453

The TAM model has been associated with a high degree of validity and reliability (Adams, Nelson \& Todd, 1992), simplicity, and higher predictive ability than the TRA and TPB (David, Bagozzi \& Warshaw, 1989; Mathieson, 1991). However, it has been criticized for: its fewer constructs relative to the TBP making it unable to capture some behavioral aspects and thus to yield less rich information (Chuttur, 2009), inconsistencies in the nature of the relationship between its variables (Szajna, 1996; Jackson et al, 1997; Davis et al, 1992; Subramanian, 1994; Gallivan et al, 2005). Other criticisms are that the model fails to explain how adoption or usage can be improved using the variables and that apart from the perceived ease of use and perceived usefulness; it fails to incorporate other factors which have an influence on technology acceptance (Al-Qeisi, 2009; Venkatesh et al., 2003).

The TAM 2 model was proposed by Venkatesh \& Davis (2000). It modified the TAM model by incorporating several variables into the TAM, including "subjective norms, image, job 
relevance, quality output, and result demonstrability” (Venkatesh \& Davis, p.453). These are viewed as influencing the perceived usefulness of the technology.

TAM2 also proposed that experience and voluntariness interact with subjective norms to shape perceived usefulness and adoption intentions. It incorporated six other factors which were viewed as impacting perceived ease of use, namely: "computer self-efficacy, perceptions of external control, computer anxiety, and computer playfulness" while the adjustments included "perceived enjoyment and objective usability" (Venkatesh \& Davis, 2000, p.453).

Consequently, the TAM 2 model has been considered a more robust model with a higher predictive ability (Chuttur, 2009), but has also been associated with several weaknesses, including: its reliance highly-subjective self-reported data, the failure to incorporate the attitude variable into the use intentions since attitudes, its deterministic nature, as well as inconsistencies in the relationships among its variables ( Legris, Ingham \& Ciollerette, 2003; Lee et al, 2003; Brown, Massey, Motoya-Weiss, \& Burkman, 2002; Davis, 1986; Bagozzi, 2007; Burton-Jones and Hubona, 2005).

The Decomposed Theory of Planned Behavior (DTPB) is grounded on the conceptual and theoretical basis of the TPB (Huang \& Chuang, 2007) and is a product of the integration of the Diffusion of Innovation and TPB models (Taylor \& Todd, 1995). It considers perceived usefulness and ease of use to be control variables for attitude and compatibility to be a precursor for perceived usefulness and ease of use (Huang \& Chuang, 2007).

The model breaks down subjective norms into two variables: peer and superior influence. It incorporates two other variables: self-efficacy and resource conditions. bEven though structural equation modeling undertaken has found the model to have a higher predictive ability than previous models (Taylor \& Todd, 1995), DTPB has been criticized as being too complex (Al-Qeisi, 2009).

Many motivational models have been proposed, with the SDT (Self-Determination Theory) of Deci \& Ryan (1985) ranking among the foremost (Al-Qeisi, 2009). According to SDT, while individuals mostly engage in self-determine volitional behavior (which is achieved through a process of choice), they may also undertake forced or mandatory behavior (which is achieved through a process of compliance). Mandatory behavior may be compelled by interpersonal or psychic influences.

The basic SDT model has been refined and expanded by various researchers. A major rendering of the SDT, accordingly, is the Hierarchical Model of Motivation of Vallerand (2001), which was modified specifically for the IS field by Davis, Bagozzi \& Warshaw (1992), and which has been further refined and extended by Davis et al (1992), Igbaria et al (1996), Venkatesh (1999), Venkatesh \& Speier (1999), and Venkatesh, Speier \& Morris (2002).

Attributed to Triandis (1977), the Model of PC Utilization differentiates between cognitive and affective variables. Later refined by Thompson et al (1991, p.129), it posits that technology acceptance is influenced by "job-fit, long-term consequences, complexity, social 
factors, facilitating conditions, affect towards use, and long-term consequences.” A major criticism of this model is that its utility is limited to the analysis of computer use in voluntary environments only (Al-Qeisi, 2009).

The Innovation Diffusion Theory (DOI) (Rogers, 1995) evaluates why, how, and at what rate different groups of people adopt new technology. It identifies five adopter categories, namely innovators, early adopters, early majority, late majority, and laggards and posits that their adoption of technology takes after a normal distribution (Al-Qeisi, 2009). Apart from individual characteristics (the individual's attitude towards change), the model also acknowledges technology adoption as being influenced by internal organizational (degree of formalization, complexity, and size, interconnectedness and slack) and external organizational characteristics (level of organizational openness).

The Social Cognitive Theory (SCT) (Bandura, 1977) assumes that: behavior is a product of a vicarious learning experience based on the observation of others or personal involvement in an experience, individuals tend to copy or imitate the behavior of those to whom they relate or are emotionally attached to, and that individual behavior is influenced by the promise of reward or threat of punishment (Al-Qeisi, 2009). SCT was applied to the IS context by Compeau \& Higgins (1995). The SCT assumes reciprocity of relationships and also acknowledges the influence of self-efficacy on individual behavior, and therefore avoids a major weakness of the prior models which all assumed unidirectional relationships between the variables.

The UTAUT is an integrative technology acceptance model formulated by synthesizing eight behavioral models, namely: the TRA, the TPB, TAM and TAM2, the motivation model, the model of PC utilization, the DOI, and the SCT (Venkatesh et al, 2003).

Unlike the previous models which focused on simple technologies targeted at individual users (and were therefore inappropriate for complex technologies in multiple-user environments), the UTAUT model is applicable to complex technologies in multi-user environments. It also avoided the methodological weaknesses of most prior models which were formulated based on sampling students. It considers both the voluntary and mandatory environments, and avoids the retrospective outlook of the previous studies (Al-Qeisi, 2009).

The Social Exchange Theory (SET) posits that behavior is based on reciprocity, interdependence, and negotiated rules (Cropanzano \& Mitchell, 2005). In the process of the exchange transaction, contingencies may arise, as the actors involved in the exchange process adjust their resources with a view of meeting each other's expectations. The theory also views power as being relational, rather than residing in the individual actor (Cropanzano \& Mitchell, 2005). It can be depicted as shown in Figure 13: 


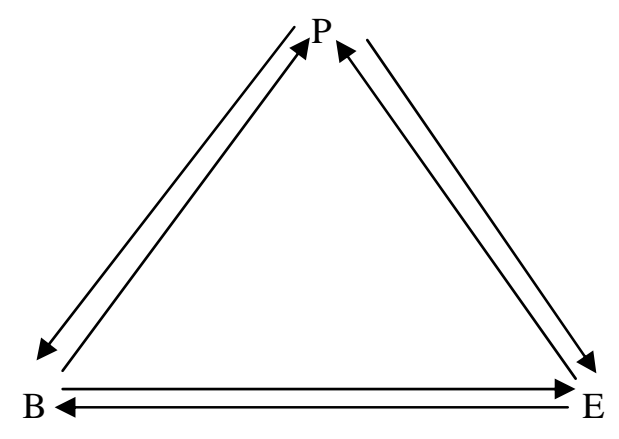

Figure 4. the SET theory

Due to its intuitive appeal, systematic approach, and high heuristic value (Thibault \& Kelley, 1952), SET has attracted enormous research interest (West \& Turner, 2000). However, it has also been criticized for its conceptual weaknesses in the definition of its variables and use of circular reasoning, its assumption that human behavior is wholly rational and made on purely cognitive considerations, and its emphasis on personal need fulfillment and self-interest (West \& Turner, 2000).

\section{Gaps in Technology Acceptance Literature}

Notwithstanding their utility, technology acceptance models have been associated with several weaknesses, including: high bias due to the use of self-reported data, inability to generalize findings due to the limiting nature of experiments used, exclusive focus on voluntary-use situations, contradictory findings regarding the relationships among the behavioral variables, determinism based on the assumption that behavioral intentions automatically lead to actual performance, their erroneous assumption that each of the variables contribute equally to behavioral intentions, and the propensity of these models to test and gauge behavioral intentions from a single perspective (Legris, Ingham, \& Collerette, 2003; Lee, Kozar, \& Larsen, 2003; Bagozzi, 2007; Lee et al, 2003).

Moreover, the use of these models in accounting for cloud computing adoption has been limited, with the few notable studies in this regard including those of Shimba (2010), Jlelaty \& Monzer (2012), and Low, Chen \& Wu (2011). However, even these few studies fail to address the weaknesses inherent in the earlier technology adoption models (Chuttur, 2009).

\section{Demographic Characteristics of the Respondents}

Only 25 of the 30 respondents sampled sent back usable responses. This translates into an $83 \%$ response rate. The demographic characteristics of these respondents are summarized in Table 3 below: 
Table 3. Demographic Characteristic of the Respondents

\begin{tabular}{|l|l|}
\hline Characteristics & Percentage \\
\hline Age & $18-24: 12 \%$ \\
& $25-29: 20 \%$ \\
& $30-34: 20 \%$ \\
& $35-39: 15 \%$ \\
& $40-44: 15 \%$ \\
& $45-49: 8 \%$ \\
& $50-54: 8 \%$ \\
& $55-59: 4 \%$ \\
& Over $60: 0 \%$ \\
\hline Gender & Male: $60 \%$ \\
& Female: $40 \%$ \\
\hline Voluntariness & Yes: $72 \%$ \\
& No: $28 \%$ \\
\hline Training & Less than 1 year: $12 \%$ \\
& $1-5$ years: $20 \%$ \\
& $6-10$ years: $30 \%$ \\
& Over 10 years: $38 \%$ \\
\hline Experience & Less than 1 year: $8 \%$ \\
& $1-5$ years: $20 \%$ \\
& $6-10$ years: $25 \%$ \\
& $11-15$ years: $25 \%$ \\
& $16-20$ years: $15 \%$ \\
& $21-25$ years: $4 \%$ \\
& $26-30$ years: $2 \%$ \\
& Over 30 years: $1 \%$ \\
\hline &
\end{tabular}

\section{Data Collected}

The data collected is summarized in Tables 4-16: 
Table 4. Responses Regarding Cloud Computing Advantages

\begin{tabular}{|c|c|c|c|c|c|}
\hline \multicolumn{6}{|c|}{ ADVANTAGES } \\
\hline \multirow{2}{*}{$\begin{array}{l}\text { Relationship } \\
\text { Cost Savings (X) and Cloud Computing (Y) }\end{array}$} & \multicolumn{5}{|c|}{ Response (number of respondents) } \\
\hline & Strongly agree (4) & Agree (11) & $\begin{array}{l}\text { Neither agree nor } \\
\text { disagree (7) }\end{array}$ & $\begin{array}{l}\text { Disagree } \\
\text { (3) }\end{array}$ & $\begin{array}{l}\text { Strongly } \\
\text { disagree (0) }\end{array}$ \\
\hline Time Savings(X) and Cloud Computing (Y) & Strongly agree (2) & Agree (7) & $\begin{array}{l}\text { Neither agree nor } \\
\text { disagree (11) }\end{array}$ & $\begin{array}{l}\text { Disagree } \\
\text { (5) }\end{array}$ & $\begin{array}{l}\text { Strongly } \\
\text { disagree (0) }\end{array}$ \\
\hline Space Savings(X) and Cloud Computing (Y) & Strongly agree (2) & Agree (12) & $\begin{array}{l}\text { Neither agree nor } \\
\text { disagree (8) }\end{array}$ & $\begin{array}{l}\text { Disagree } \\
\text { (3) }\end{array}$ & $\begin{array}{l}\text { Strongly } \\
\text { disagree (0) }\end{array}$ \\
\hline Automation (X) and Cloud Computing (Y) & Strongly agree (0) & Agree (11) & $\begin{array}{l}\text { Neither agree nor } \\
\text { disagree (9) }\end{array}$ & $\begin{array}{l}\text { Disagree } \\
\text { (5) }\end{array}$ & $\begin{array}{l}\text { Strongly } \\
\text { disagree (0) }\end{array}$ \\
\hline $\begin{array}{l}\text { Remote Implementation } \quad(\mathrm{X}) \text { and Cloud } \\
\text { Computing (Y) }\end{array}$ & Strongly agree (3) & Agree (12) & $\begin{array}{l}\text { Neither agree nor } \\
\text { disagree (8) }\end{array}$ & $\begin{array}{l}\text { Disagree } \\
\text { (2) }\end{array}$ & $\begin{array}{l}\text { Strongly } \\
\text { disagree (0) }\end{array}$ \\
\hline Scalability (X) and Cloud Computing (Y) & Strongly agree (8) & Agree (9) & $\begin{array}{l}\text { Neither agree nor } \\
\text { disagree (6) }\end{array}$ & $\begin{array}{l}\text { Disagree } \\
\text { (2) }\end{array}$ & $\begin{array}{l}\text { Strongly } \\
\text { disagree (0) }\end{array}$ \\
\hline Flexibility $\quad(\mathrm{X})$ and Cloud Computing (Y) & Strongly agree (4) & Agree (12) & $\begin{array}{l}\text { Neither agree nor } \\
\text { disagree }(6)\end{array}$ & $\begin{array}{l}\text { Disagree } \\
\text { (3) }\end{array}$ & $\begin{array}{l}\text { Strongly } \\
\text { disagree (0) }\end{array}$ \\
\hline $\begin{array}{l}\text { Business Mobility (X) and Cloud Computing } \\
\text { (Y) }\end{array}$ & Strongly agree (1) & Agree (11) & $\begin{array}{l}\text { Neither agree nor } \\
\text { disagree (8) }\end{array}$ & $\begin{array}{l}\text { Disagree } \\
\text { (5) }\end{array}$ & $\begin{array}{l}\text { Strongly } \\
\text { disagree (0) }\end{array}$ \\
\hline
\end{tabular}

Key: 5=strongly agree; 4=agree; 3=neither agree nor disagree; 2=disagree; 1=strongly disagree.

Table 5. Responses Regarding Cloud Computing Disadvantages

\begin{tabular}{|l|l|l|l|l|l|l|}
\hline \multicolumn{7}{|c|}{ DISADVANTAGES } \\
\hline Relationship & \multicolumn{5}{|c|}{ Response (number of respondents) } \\
\hline Security Risks $\quad(\mathrm{X})$ and Cloud Computing (Y) & Strongly agree (9) & Agree (8) & Neither agree nor disagree (3) & Disagree (3) & Strongly disagree (2) \\
\hline System Outages (X) and Cloud Computing (Y) & Strongly agree (2) & Agree (12) & Neither agree nor disagree (4) & Disagree (7) & Strongly disagree (0) \\
\hline Privacy Infringement (X) and Cloud Computing (Y) & Strongly agree (8) & Agree (10) & Neither agree nor disagree (3) & Disagree (4) & Strongly disagree (0) \\
\hline Intermittency (X) and Cloud Computing (Y) & Strongly agree (0) & Agree (12) & Neither agree nor disagree (7) & Disagree (6) & Strongly disagree (0) \\
\hline Patriot Act $(\mathrm{X})$ and Cloud Computing (Y) & Strongly agree (2) & Agree (14) & Neither agree nor disagree (5) & Disagree (3) & Strongly disagree (1) \\
\hline Loss of Control (X) and Cloud Computing (Y) & Strongly agree (5) & Agree (11) & Neither agree nor disagree (6) & Disagree (2) & Strongly disagree (1) \\
\hline Lack of Standards (X) and Cloud Computing (Y) & Strongly agree (5) & Agree (11) & Neither agree nor disagree (6) & Disagree (2) & Strongly disagree (1) \\
\hline Data Loss (X) and Cloud Computing (Y) & Strongly agree (5) & Agree (11) & Neither agree nor disagree (6) & Disagree (2) & Strongly disagree (1) \\
\hline
\end{tabular}

Key: 5=strongly agree; 4=agree; 3=neither agree nor disagree; $2=$ disagree; 1 =strongly disagree. 


\section{Macrothink}

Journal of Management Research

ISSN 1941-899X

2013, Vol. 5, No. 1

Table 6. Responses Regarding Cloud Computing Adoption Intentions and Actual Adoption

\begin{tabular}{|l|l|l|l|l|l|}
\hline Relationship & \multicolumn{5}{|c|}{ Response (number of respondents) } \\
\hline Adoption Intentions (X) & Strongly agree (2) & Agree (7) & Neither agree nor disagree (7) & Disagree (7) & Strongly disagree (2) \\
\hline Actual Adoption (Y) & Very high (1) & High (7) & Neither high nor low (6) & Low (7) & Very low (4) \\
\hline
\end{tabular}

Key: 5= very high; 4=high; $3=$ neither high nor low; $2=$ low; $1=$ very low.

\section{Data Quality Assessment}

The Cronbach's alpha analysis of the data quality is given in Table 7 below:

Table 7. Cronbach’s Alpha

\begin{tabular}{|l|l|}
\hline Construct & Cronbach's Alpha \\
\hline Advantages & 0.928 \\
\hline Disadvantages & 0.860 \\
\hline Behavioral intentions & 0.735 \\
\hline
\end{tabular}

In line with Venkatesh et al (2003), all the constructs return alpha coefficients $>0.70$, pointing to a high degree of reliability.

\section{Cross Tabulation of Results}

The result of the analysis of the data in Tables 9-11 is presented in Tables 13-14:

Table 8. Pearson's r for the Advantages

\begin{tabular}{|l|l|l|l|l|}
\hline Variable & Pearson's r & T-statistic & 1-tailed test & 2-tailed test \\
\hline Cost savings & 0.771255061 & 1.049908145 & 0.015854206 & 0.031708411 \\
\hline Time savings & 0.669294153 & 0.768541101 & 0.085070777 & 0.170141553 \\
\hline Space savings & 0.687739906 & 0.611641178 & 0.128170602 & 0.256341204 \\
\hline Automation & 0.698035556 & -0.46678887 & 0.188237555 & 0.37647511 \\
\hline Remote implementation & 0.693601208 & 1.061639607 & 0.02498521 & 0.049970421 \\
\hline Scalability & 0.799650999 & 0.549327711 & 0.106212724 & 0.212425448 \\
\hline Flexibility & 0.517412626 & 0.55260402 & 0.212700225 & 0.42540045 \\
\hline Mobile business & 0.607721699 & -1.74347795 & 0.003770789 & 0.007541578 \\
\hline
\end{tabular}


Table 9. Pearson's r for the Disadvantages

\begin{tabular}{|l|l|l|l|l|}
\hline Variable & Pearson's $\mathrm{r}$ & T-statistic & One-tailed test & Two-tailed test \\
\hline Security risks versus & -0.87848179 & 5.504195815 & 0.000642133 & 0.001284266 \\
\hline System outages & -0.02799463 & 4.491745614 & 0.000121563 & 0.000243126 \\
\hline Privacy infringement & -0.89119442 & 6.127612605 & 0.000123438 & 0.000246876 \\
\hline Intermittency & -0.48808617 & 4.242341984 & 0.000888463 & 0.001776927 \\
\hline PATRIOT Act & -0.84555863 & 5.093131884 & 0.000597394 & 0.001194787 \\
\hline Loss of control & -0.84019217 & 5.568414474 & 0.000292214 & 0.000584428 \\
\hline Lack of standards & -0.79513220 & 5.227631497 & 0.000534473 & 0.001068946 \\
\hline Loss of data & -0.16729650 & 4.645340948 & 0.000121563 & 0.000243126 \\
\hline
\end{tabular}

As Table 8 shows, all the advantages are positively correlated with behavioral intentions. The relationship for all the variables is strong and significant $(0<\mathrm{r}>0.5)$; paired tests $<$ critical value), with scalability and cost savings being the strongest drivers. From Table 9, all the disadvantages are negatively correlated with behavioral intentions. The relationship for all the variables is strong and significant $(0<\mathrm{r}>0.5$; paired tests $<$ critical value), with the exception of data loss where the relationship is weak $(0<r<0.5)$. The analysis of the relationship between adoption intentions and actual behavioral performance is presented in Table 10 below:

Table 10. Adoption Intentions and Actual Behavioral Performance

\begin{tabular}{|c|l|l|l|l|}
\hline Relationship & Pearson's r & T-statistic & One-tailed test & Two-tailed test \\
\hline Adoption intentions versus actual behavior & 0.735910519 & 0.776028991 & 0.080745951 & 0.161491902 \\
\hline
\end{tabular}

From Table 10, adoption intentions are positively, strongly, and significantly correlated with actual behavior $(0<\mathrm{r}>0.5$; paired test value $<$ critical value).

\section{Analysis of Relationships in TAM Framework}

That the interplay of the various advantages and disadvantages either affects behavioral intentions positively or negatively, and that behavioral intentions also affect actual behavior either positively or negatively, validates the basic claims of the TAM model.

\section{Hypotheses Testing}

The proposed Triple-T model is represented by the equation below:

$$
\mathrm{AI}=\sum_{\mathrm{i}=1}^{\mathrm{n}} \mathrm{WiAi}-\sum_{\mathrm{i}=1}^{\mathrm{n}} \mathrm{WiDi} \quad(17.1)
$$

Where: AI refers to the Adoption Intention; individual's intention to carry out adoption A, Wi refers to the weight assigned to each advantage and/or disadvantage using 9-point Likert scale, Ai refers to the score assigned to each advantage using 5-point Likert scale, Di refers to 


\section{Macrothink}

Journal of Management Research

ISSN 1941-899X

2013, Vol. 5, No. 1

the score assigned to each disadvantage using 5-point Likert scale and $\mathrm{n}$ represents the number of the potential advantages and/or disadvantages of technology.

The null hypothesis is rejected when $\Sigma \mathrm{WiAi}\rangle \Sigma \mathrm{WiDi}$. Otherwise, it is affirmed. The data collected with regards to the various advantages and disadvantages, including the weights attached to each of these by the respondents, are summarized in Tables 11-14 below:

Table 11. Advantages: Scoring and Weighting

\begin{tabular}{|c|c|c|c|c|c|c|c|c|c|c|c|c|c|c|c|c|}
\hline Respondent & $\begin{array}{l}\text { CSA } \\
\text { (Ai) }\end{array}$ & $\begin{array}{l}\text { Wt. } \\
\text { (Wi) }\end{array}$ & $\begin{array}{l}\text { TSA } \\
\text { (Aii) }\end{array}$ & $\begin{array}{l}\text { Wt. } \\
\text { (Wii) }\end{array}$ & $\begin{array}{l}\text { SSA } \\
\text { (Aiii) }\end{array}$ & $\begin{array}{l}\text { Wt. } \\
\text { (wiii) }\end{array}$ & $\begin{array}{l}\text { HA } \\
\text { (Aiv) }\end{array}$ & $\begin{array}{l}\text { Wt. } \\
\text { (Wiv) }\end{array}$ & $\begin{array}{l}\text { RIA } \\
\text { (Av) }\end{array}$ & $\begin{array}{l}\text { Wt. } \\
(\mathrm{Wv})\end{array}$ & $\begin{array}{l}\text { SCA } \\
\text { (Avi) }\end{array}$ & $\begin{array}{l}\text { Wt. } \\
\text { (Wvi) }\end{array}$ & $\begin{array}{l}\text { FLA } \\
\text { (Avii) }\end{array}$ & $\begin{array}{l}\text { Wt. } \\
\text { (Wvii) }\end{array}$ & $\begin{array}{l}\text { MBA } \\
\text { (Aviii) }\end{array}$ & $\begin{array}{l}\text { Wt. } \\
\text { (Wviii) }\end{array}$ \\
\hline 1 & 4 & 0.9 & 4 & 0.7 & 4 & 0.5 & 4 & 0.4 & 3 & 0.2 & 4 & 0.8 & 4 & 0.6 & 4 & 0.7 \\
\hline 2 & 3 & 0.8 & 3 & 0.9 & 4 & 0.2 & 4 & 0.3 & 4 & 0.3 & 3 & 0.7 & 5 & 0.7 & 4 & 0.6 \\
\hline 3 & 3 & 0.9 & 4 & 0.9 & 3 & 0.6 & 4 & 0.3 & 3 & 0.4 & 4 & 0.9 & 4 & 0.6 & 3 & 0.4 \\
\hline 4 & 3 & 0.9 & 4 & 0.8 & 4 & 0.3 & 3 & 0.2 & 3 & 0.3 & 3 & 0.4 & 4 & 0.6 & 3 & 0.3 \\
\hline 5 & 4 & 0.8 & 4 & 0.9 & 4 & 0.6 & 4 & 0.4 & 4 & 0.2 & 4 & 0.6 & 4 & 0.7 & 4 & 0.6 \\
\hline 6 & 4 & 0.9 & 4 & 0.8 & 5 & 0.3 & 3 & 0.1 & 4 & 0.4 & 4 & 0.5 & 5 & 0.8 & 3 & 0.5 \\
\hline 7 & 2 & 0.8 & 3 & 0.9 & 3 & 0.3 & 3 & 0.2 & 3 & 0.3 & 2 & 0.3 & 3 & 0.3 & 4 & 0.3 \\
\hline 8 & 5 & 0.8 & 4 & 0.8 & 4 & 0.4 & 4 & 0.5 & 3 & 0.3 & 5 & 0.9 & 4 & 0.6 & 4 & 0.5 \\
\hline 9 & 4 & 0.9 & 4 & 0.9 & 3 & 0.2 & 3 & 0.3 & 5 & 0.2 & 5 & 0.8 & 5 & 0.8 & 3 & 0.3 \\
\hline 10 & 5 & 0.8 & 4 & 0.8 & 4 & 0.5 & 4 & 0.4 & 4 & 0.6 & 5 & 0.7 & 4 & 0.5 & 4 & 0.6 \\
\hline 11 & 3 & 0.8 & 3 & 0.8 & 3 & 0.2 & 2 & 0.5 & 3 & 0.2 & 3 & 0.4 & 3 & 0.4 & 2 & 0.3 \\
\hline 12 & 4 & 0.9 & 3 & 0.7 & 4 & 0.3 & 3 & 0.2 & 4 & 0.2 & 4 & 0.4 & 4 & 0.3 & 3 & 0.3 \\
\hline 13 & 2 & 0.8 & 2 & 0.8 & 2 & 0.2 & 2 & 0.2 & 2 & 0.4 & 2 & 0.2 & 2 & 0.2 & 2 & 0.2 \\
\hline 14 & 5 & 0.9 & 4 & 0.9 & 3 & 0.4 & 4 & 0.4 & 4 & 0.2 & 5 & 0.7 & 3 & 0.4 & 4 & 0.5 \\
\hline 15 & 4 & 0.9 & 3 & 0.9 & 4 & 0.5 & 4 & 0.2 & 3 & 0.3 & 5 & 0.8 & 4 & 0.8 & 4 & 0.6 \\
\hline 16 & 4 & 0.9 & 4 & 0.8 & 4 & 0.6 & 3 & 0.4 & 4 & 0.2 & 4 & 0.6 & 4 & 0.6 & 3 & 0.4 \\
\hline 17 & 4 & 0.8 & 2 & 0.9 & 3 & 0.3 & 3 & 0.1 & 4 & 0.4 & 4 & 0.5 & 3 & 0.4 & 3 & 0.4 \\
\hline 18 & 3 & 0.8 & 3 & 0.8 & 2 & 0.2 & 2 & 0.2 & 3 & 0.3 & 3 & 0.3 & 2 & 0.3 & 2 & 0.3 \\
\hline 19 & 3 & 0.9 & 4 & 0.8 & 3 & 0.4 & 3 & 0.3 & 4 & 0.5 & 3 & 0.4 & 3 & 0.3 & 3 & 0.3 \\
\hline 20 & 4 & 0.8 & 5 & 0.8 & 4 & 0.1 & 4 & 0.1 & 4 & 0.4 & 4 & 0.7 & 4 & 0.7 & 4 & 0.6 \\
\hline 21 & 3 & 0.9 & 3 & 0.8 & 3 & 0.3 & 2 & 0.2 & 4 & 0.5 & 3 & 0.5 & 3 & 0.4 & 2 & 0.2 \\
\hline 22 & 2 & 0.8 & 2 & 0.9 & 2 & 0.3 & 2 & 0.2 & 2 & 0.4 & 2 & 0.3 & 2 & 0.3 & 2 & 0.3 \\
\hline 23 & 4 & 0.9 & 4 & 0.8 & 4 & 0.2 & 3 & 0.2 & 4 & 0.3 & 5 & 0.9 & 4 & 0.8 & 4 & 0.6 \\
\hline 24 & 4 & 0.9 & 4 & 0.8 & 5 & 0.1 & 4 & 0.5 & 5 & 0.2 & 4 & 0.8 & 5 & 0.9 & 4 & 0.7 \\
\hline 25 & 5 & 0.9 & 5 & 0.8 & 4 & 0.1 & 4 & 0.2 & 5 & 0.3 & 5 & 0.8 & 4 & 0.7 & 4 & 0.7 \\
\hline
\end{tabular}

Where: CSA=cost saving advantages; Wt. = weight attached to each specific advantage; $\mathrm{TSA}=$ time savings; $\mathrm{SSA}=$ space savings; $\mathrm{HA}=$ high automation; $\mathrm{RIA}=$ remote implementation; SCA = scalability; FLA = flexibility; and MBA = mobile business. Given 
that the Triple-T model is represented by the equation $\Sigma \mathrm{WiAi}>\Sigma \mathrm{WiDi}$, table 12 shows the summation of the values of the advantages:

Table 12. $\Sigma$ WiAi

\begin{tabular}{|c|c|c|c|c|c|c|c|c|}
\hline Respondent & AiWi & AiiWii & AiiiWiii & AivWiv & AvWv & AviWvi & AviiWvii & AviiiWviii \\
\hline 1 & 3.6 & 2.8 & 2 & 1.6 & 0.6 & 3.2 & 2.4 & 2.8 \\
\hline 2 & 2.4 & 2.7 & 0.8 & 1.2 & 1.2 & 2.1 & 3.5 & 2.4 \\
\hline 3 & 2.7 & 3.6 & 1.8 & 1.2 & 1.2 & 3.6 & 2.4 & 1.2 \\
\hline 4 & 2.7 & 3.2 & 1.2 & 0.6 & 0.9 & 1.2 & 2.4 & 0.9 \\
\hline 5 & 3.2 & 3.6 & 2.4 & 1.6 & 0.8 & 2.4 & 2.8 & 2.4 \\
\hline 6 & 3.6 & 3.2 & 1.5 & 0.3 & 1.6 & 2 & 4 & 1.5 \\
\hline 7 & 1.6 & 2.7 & 0.9 & 0.6 & 0.9 & 0.6 & 0.9 & 1.2 \\
\hline 8 & 4 & 3.2 & 1.6 & 2 & 0.9 & 4.5 & 2.4 & 2 \\
\hline 9 & 3.6 & 3.6 & 0.6 & 0.9 & 1 & 4 & 4 & 0.9 \\
\hline 10 & 4 & 3.2 & 2 & 1.6 & 2.4 & 3.5 & 2 & 2.4 \\
\hline 11 & 2.4 & 2.4 & 0.6 & 1 & 0.6 & 1.2 & 1.2 & 0.6 \\
\hline 12 & 3.6 & 2.1 & 1.2 & 0.6 & 0.8 & 1.6 & 1.2 & 0.9 \\
\hline 13 & 1.6 & 1.6 & 0.4 & 0.4 & 0.8 & 0.4 & 0.4 & 0.4 \\
\hline 14 & 4.5 & 3.6 & 1.2 & 1.6 & 0.8 & 3.5 & 1.2 & 2 \\
\hline 15 & 3.6 & 2.7 & 2 & 0.8 & 0.9 & 4 & 3.2 & 2.4 \\
\hline 16 & 3.6 & 3.2 & 2.4 & 1.2 & 0.8 & 2.4 & 2.4 & 1.2 \\
\hline 17 & 3.2 & 1.8 & 0.9 & 0.3 & 1.6 & 2 & 1.2 & 1.2 \\
\hline 18 & 2.4 & 2.4 & 0.4 & 0.4 & 0.9 & 0.9 & 0.6 & 0.6 \\
\hline 19 & 2.7 & 3.2 & 1.2 & 0.9 & 2 & 1.2 & 0.9 & 0.9 \\
\hline 20 & 3.2 & 4 & 0.4 & 0.4 & 1.6 & 2.8 & 2.8 & 2.4 \\
\hline 21 & 2.7 & 2.4 & 0.9 & 0.4 & 2 & 1.5 & 1.2 & 0.4 \\
\hline 22 & 1.6 & 1.8 & 0.6 & 0.4 & 0.8 & 0.6 & 0.6 & 0.6 \\
\hline 23 & 3.6 & 3.2 & 0.8 & 0.6 & 1.2 & 4.5 & 3.2 & 2.4 \\
\hline 24 & 3.6 & 3.2 & 0.5 & 2 & 1 & 3.2 & 4.5 & 2.8 \\
\hline 25 & 4.5 & 4 & 0.4 & 0.8 & 1.5 & 4 & 2.8 & 2.8 \\
\hline$\Sigma$ & 78.2 & 73.4 & 28.7 & 23.4 & 28.8 & 60.9 & 54.2 & 39.3 \\
\hline
\end{tabular}

From Table 12, $\Sigma \mathrm{WiDi}=(78.2+73.4+28.7+23.4+28.8+60.9+54.2+39.3)=\underline{386.9}$. 
Table 13. Disadvantages: Weighting and Scoring

\begin{tabular}{|c|c|c|c|c|c|c|c|c|c|c|c|c|c|c|c|c|}
\hline Respondent & $\begin{array}{l}\text { SRD } \\
\text { (Di) }\end{array}$ & $\begin{array}{l}\text { Wt. } \\
\text { (Wi) }\end{array}$ & $\begin{array}{l}\text { SOD } \\
\text { (Dii) }\end{array}$ & $\begin{array}{l}\text { Wt. } \\
\text { (Wii) }\end{array}$ & $\begin{array}{l}\text { PD } \\
\text { (Diii) }\end{array}$ & $\begin{array}{l}\text { Wt. } \\
\text { (wiii) }\end{array}$ & $\begin{array}{l}\text { HID } \\
\text { (Div) }\end{array}$ & $\begin{array}{l}\text { Wt. } \\
\text { (Wiv) }\end{array}$ & $\begin{array}{l}\text { PAD } \\
\text { (Dv) }\end{array}$ & $\begin{array}{l}\text { Wt. } \\
(W v)\end{array}$ & $\begin{array}{l}\text { LCD } \\
\text { (Dvi) }\end{array}$ & $\begin{array}{l}\text { Wt. } \\
\text { (Wvi) }\end{array}$ & $\begin{array}{l}\text { SD } \\
\text { (Dvii) }\end{array}$ & $\begin{array}{l}\text { Wt. } \\
\text { (Wvii) }\end{array}$ & $\begin{array}{l}\text { DLD } \\
\text { (Dviii) }\end{array}$ & $\begin{array}{l}\text { Wt. } \\
\text { (Wviii) }\end{array}$ \\
\hline 1 & 5 & 0.7 & 5 & 0.3 & 5 & 0.7 & 3 & 0.3 & 4 & 0.4 & 5 & 0.8 & 4 & 0.6 & 4 & 0.7 \\
\hline 2 & 4 & 0.8 & 3 & 0.5 & 4 & 0.8 & 2 & 0.4 & 4 & 0.2 & 4 & 0.6 & 4 & 0.5 & 2 & 0.4 \\
\hline 3 & 3 & 0.7 & 2 & 0.3 & 4 & 0.8 & 2 & 0.4 & 4 & 0.4 & 3 & 0.3 & 3 & 0.4 & 3 & 0.3 \\
\hline 4 & 2 & 0.9 & 4 & 0.4 & 4 & 0.7 & 3 & 0.5 & 4 & 0.2 & 4 & 0.3 & 2 & 0.3 & 3 & 0.3 \\
\hline 5 & 4 & 0.7 & 4 & 0.2 & 2 & 0.3 & 4 & 0.6 & 2 & 0.3 & 2 & 0.3 & 4 & 0.4 & 4 & 0.5 \\
\hline 6 & 2 & 0.8 & 2 & 0.3 & 3 & 0.6 & 2 & 0.6 & 3 & 0.4 & 3 & 0.4 & 2 & 0.3 & 2 & 0.3 \\
\hline 7 & 5 & 0.9 & 4 & 0.2 & 5 & 0.9 & 3 & 0.5 & 5 & 0.4 & 4 & 0.4 & 4 & 0.4 & 3 & 0.3 \\
\hline 8 & 4 & 0.8 & 4 & 0.5 & 4 & 0.7 & 4 & 0.7 & 4 & 0.1 & 4 & 0.2 & 4 & 0.5 & 4 & 0.6 \\
\hline 9 & 1 & 0.6 & 3 & 0.4 & 2 & 0.4 & 2 & 0.4 & 2 & 0.3 & 3 & 0.3 & 2 & 0.3 & 3 & 0.3 \\
\hline 10 & 3 & 0.7 & 4 & 0.2 & 2 & 0.4 & 4 & 0.5 & 3 & 0.4 & 2 & 0.3 & 3 & 0.4 & 4 & 0.4 \\
\hline 11 & 5 & 0.8 & 4 & 0.4 & 5 & 0.8 & 4 & 0.5 & 4 & 0.5 & 4 & 0.6 & 4 & 0.7 & 3 & 0.4 \\
\hline 12 & 5 & 0.8 & 3 & 0.3 & 5 & 0.6 & 3 & 0.6 & 4 & 0.2 & 5 & 0.3 & 5 & 0.8 & 3 & 0.5 \\
\hline 13 & 5 & 0.7 & 4 & 0.3 & 4 & 0.6 & 3 & 0.6 & 3 & 0.1 & 4 & 0.5 & 4 & 0.6 & 3 & 0.4 \\
\hline 14 & 4 & 0.9 & 2 & 0.3 & 4 & 0.5 & 4 & 0.7 & 4 & 0.4 & 4 & 0.6 & 4 & 0.5 & 5 & 0.7 \\
\hline 15 & 2 & 0.7 & 2 & 0.1 & 3 & 0.6 & 2 & 0.4 & 2 & 0.2 & 3 & 0.2 & 2 & 0.4 & 2 & 0.2 \\
\hline 16 & 4 & 0.6 & 4 & 0.4 & 4 & 0.7 & 4 & 0.3 & 4 & 0.3 & 4 & 0.3 & 4 & 0.3 & 4 & 0.3 \\
\hline 17 & 4 & 0.8 & 4 & 0.1 & 4 & 0.6 & 4 & 0.4 & 3 & 0.4 & 3 & 0.4 & 4 & 0.5 & 5 & 0.6 \\
\hline 18 & 3 & 0.7 & 2 & 0.2 & 3 & 0.5 & 4 & 0.5 & 3 & 0.1 & 3 & 0.3 & 3 & 0.3 & 4 & 0.4 \\
\hline 19 & 4 & 0.8 & 3 & 0.4 & 4 & 0.7 & 3 & 0.6 & 4 & 0.2 & 4 & 0.2 & 4 & 0.3 & 3 & 0.3 \\
\hline 20 & 5 & 0.7 & 3 & 0.2 & 5 & 0.6 & 4 & 0.5 & 4 & 0.5 & 5 & 0.4 & 5 & 0.4 & 4 & 0.4 \\
\hline 21 & 4 & 0.8 & 2 & 0.3 & 4 & 0.6 & 3 & 0.6 & 4 & 0.3 & 4 & 0.3 & 4 & 0.3 & 3 & 0.3 \\
\hline 22 & 5 & 0.7 & 4 & 0.5 & 5 & 0.7 & 4 & 0.7 & 5 & 0.1 & 5 & 0.6 & 5 & 0.6 & 2 & 0.4 \\
\hline 23 & 1 & 0.7 & 5 & 0.6 & 2 & 0.3 & 2 & 0.3 & 1 & 0.2 & 1 & 0.2 & 1 & 0.1 & 3 & 0.2 \\
\hline 24 & 5 & 0.7 & 4 & 0.2 & 4 & 0.8 & 4 & 0.5 & 4 & 0.4 & 4 & 0.4 & 5 & 0.6 & 4 & 0.5 \\
\hline 25 & 5 & 0.8 & 2 & 0.3 & 5 & 0.9 & 4 & 0.6 & 4 & 0.1 & 5 & 0.4 & 4 & 0.4 & 4 & 0.4 \\
\hline
\end{tabular}

Where: SRD =security risks disadvantage; Wt. = weight attached to each specific disadvantage; SOD =system outages; PD = privacy infringement; HID = intermittency; $\mathrm{PAD}=$ patriot act; $\mathrm{DLD}=$ data loss; $\mathrm{SD}=$ lack of standards; and LCD = loss of control. Given that the proposed Triple-T model is represented by the equation

$\Sigma$ WiAi $>\Sigma$ WiDi, Table 14 shows the summation of the values of the disadvantages: 
Table 14. $\Sigma \mathrm{WiDi}$

\begin{tabular}{|c|c|c|c|c|c|c|c|c|}
\hline Respondent & DiWi & DiiWii & DiiiWiii & DivWiv & DvWv & DviWvi & DviiWvii & DviiiWviii \\
\hline 1 & 3.5 & 1.5 & 3.5 & 0.9 & 1.6 & 4 & 2.4 & 2.8 \\
\hline 2 & 3.2 & 1.5 & 3.2 & 0.8 & 0.8 & 2.4 & 2 & 0.8 \\
\hline 3 & 2.1 & 0.6 & 3.2 & 0.8 & 1.6 & 0.9 & 1.2 & 0.9 \\
\hline 4 & 1.8 & 1.6 & 2.8 & 1.5 & 0.8 & 1.2 & 0.6 & 0.9 \\
\hline 5 & 2.8 & 0.8 & 0.6 & 2.4 & 0.6 & 0.6 & 1.6 & 2 \\
\hline 6 & 1.6 & 0.6 & 1.8 & 1.2 & 1.2 & 1.2 & 0.6 & 0.6 \\
\hline 7 & 4.5 & 0.8 & 4.5 & 1.5 & 2 & 1.6 & 1.6 & 0.9 \\
\hline 8 & 3.2 & 2 & 2.8 & 2.8 & 0.4 & 0.8 & 2 & 2.4 \\
\hline 9 & 0.6 & 1.2 & 0.8 & 0.8 & 0.6 & 0.9 & 0.6 & 0.9 \\
\hline 10 & 2.1 & 0.8 & 0.8 & 2 & 1.2 & 0.6 & 1.2 & 1.6 \\
\hline 11 & 4 & 1.6 & 4 & 2 & 2 & 2.4 & 2.8 & 1.2 \\
\hline 12 & 4 & 0.9 & 3 & 1.8 & 0.8 & 1.5 & 4 & 1.5 \\
\hline 13 & 3.5 & 1.2 & 2.4 & 1.8 & 0.3 & 2 & 2.4 & 1.2 \\
\hline 14 & 3.6 & 0.6 & 2 & 2.8 & 1.6 & 2.4 & 2 & 3.5 \\
\hline 15 & 1.4 & 0.2 & 1.8 & 0.8 & 0.4 & 0.6 & 0.8 & 0.4 \\
\hline 16 & 2.4 & 1.6 & 2.8 & 1.2 & 1.2 & 1.2 & 1.2 & 1.2 \\
\hline 17 & 3.2 & 0.4 & 2.4 & 1.6 & 1.2 & 1.2 & 2 & 3 \\
\hline 18 & 2.1 & 0.4 & 1.5 & 2 & 0.3 & 0.9 & 0.9 & 1.6 \\
\hline 19 & 3.2 & 1.2 & 2.8 & 1.8 & 0.8 & 0.8 & 1.2 & 0.9 \\
\hline 20 & 3.5 & 0.6 & 3 & 2 & 2 & 2 & 2 & 1.6 \\
\hline 21 & 3.2 & 0.6 & 2.4 & 1.8 & 1.2 & 1.2 & 1.2 & 0.9 \\
\hline 22 & 3.5 & 2 & 3.5 & 2.8 & 0.5 & 3 & 3 & 0.8 \\
\hline 23 & 0.7 & 3 & 0.6 & 0.6 & 0.2 & 0.2 & 0.1 & 0.6 \\
\hline 24 & 3.5 & 0.8 & 3.2 & 2 & 1.6 & 1.6 & 3 & 2 \\
\hline 25 & 4 & 0.6 & 4.5 & 2.4 & 0.4 & 2 & 1.6 & 1.6 \\
\hline$\Sigma$ & 71.2 & 27.1 & 63.9 & 42.1 & 25.3 & 37.2 & 42 & 35.8 \\
\hline
\end{tabular}

From Table 14, $\Sigma \mathrm{WiDi}=(71.2+27.1+63.9+42.1+25.3+37.2+42+35.8)=\underline{344.6}$. To get the sdoption intention value (AI), we substitute the values from Tables 12 and 14 into equation:

$$
\mathrm{AI}=\sum_{\mathrm{i}=1}^{\mathrm{n}} \mathrm{WiAi}-\sum_{\mathrm{i}=1}^{\mathrm{n}} \mathrm{WiDi} \quad(17.1)
$$

on the basis of which the study hypothesis is evaluated:

- $\quad \mathrm{H} 1_{\mathrm{A}}$ : the advantages of cloud computing initiatives outweigh its disadvantages

- $\mathrm{H} 1_{0}$ : the advantages of cloud computing initiatives do not outweigh its disadvantages

Accordingly, $386.9>344.6$ and the null hypothesis is rejected. The study concludes that the adoption of cloud computing leads to a net balance of benefits over costs and organizations should adopt cloud computing systems. It also shows that one advantage may outweigh many 
disadvantages, or that one disadvantage may outweigh many disadvantages, and that buy or reject decisions may be made on the basis of that.

\section{Conclusion}

Since the Triple-T model proposes sixteen variables for the evaluation of technology acceptance, it breaks ranks with all the previous technology adoption models by testing and gauging adopter acceptance from multiple perspectives without necessarily losing its parsimony.

Given the overall findings that the adoption of cloud computing leads to a balance of benefits over costs; managers should ensure that their organizations adopt cloud computing technology. This would help improve their organizations' overall performance. Such an improvement would arise from cost savings, time and space efficiencies, increased flexibility arising from scalability, and improved output quality. At the same time, they will need to work to minimize the disadvantages associated with cloud computing by for example: enhancing their data security using such measures as firewalls. They may also want to negotiate for service level agreements which guarantee protection against privacy infringement or data loss. Adoption of cloud computing may result to automation, leading to staff redundancies. Affected staff may oppose this, and the adoption of the technology thus calls for change management initiatives. Since the model focuses on advantages and disadvantages as the starting point, marketers of cloud computing initiatives must focus on selling benefits rather than product features.

Since the study evinces overall net benefits accruing from the adoption of cloud computing, policymakers need to formulate policies which will encourage the acceptance of this technology. They can do this by crafting policies designed to minimize the impact of its disadvantages. For example, they must formulate laws which guarantee privacy protection and protection against cyber security threats. They must also put in place measures which guarantee resource availability (e.g. fast and reliable internet, reliable power supply).

\section{References}

Adams, D. A., Nelson, R. R., \& Todd, P. A. (1992). Perceived usefulness, ease of use, and usage of information technology: A replication. MIS Quarterly, 16, 227-247. http://dx.doi.org/10.2307/249577

Ahronovitz M., Amrhein D., Anderson P., DeAndrade A., Armstrong J., Arasan B.E., Bartlett J., Bruklis R., Cameron K., Carlson M., Cohen R., Crawford T.M., Deolaliker V., Downing P., Easton A., \& Flores R. (2010). Cloud computing use cases. White Paper.

Al-Qeisi, KI. (2009). Analyzing the use of UTAUT model in explaining an online behaviour: internet banking adoption. Brunel University.

Bagozzi, R. P., \& Kimmel, S. K. (1995). A comparison of leading theories for the prediction of goal-directed behaviors. British Journal of Social Psychology, 34, 437-461. http://dx.doi.org/10.1111/j.2044-8309.1995.tb01076.x 
Bagozzi, R.P. (2007). The legacy of the technology acceptance model and a proposal for a paradigm shift. Journal of the association for information systems, 8(4), 244-254.

Bandura, A. (1977). Social learning theory. Englewood Cliffs, NJ: Prentice-Hall.

Behrend, T.S., Wiebe, E.N., London, J.E., \& Johnson, E.C. (2011). Cloud computing adoption and usage in community colleges. Behavior \& Information Technology, 30(2), 231-240. http://dx.doi.org/10.1080/0144929X.2010.489118

Brown, S., Massey, A., Montoya-Weiss, M., \& Burkman, J. (2002). Do I really have to? User Acceptance of mandated technology. European journal of information systems, 11, 283-295. http://dx.doi.org/10.1057/palgrave.ejis.3000438

Burton- Jones, A., \& Hubona, G. (2005). Individual differences and usage behavior: Revisiting a technology acceptance model assumption. ACM SIGMIS Database, 36(2), 58-77.

Buyya, R., Yeo, C. S., et al. (2008). Market-oriented cloud computing: Vision, hype, and reality for delivering IT services as computing utilities. 10th IEEE Conference on High Performance Computing and Communications. IEEE. http://dx.doi.org/10.1109/HPCC.2008.172

Chuttur, M.Y. (2009). Overview of the technology acceptance model: Origins, developments and future directions. Sprouts: Working Papers on Information Systems, 9(37), 1-23.

Compeau, D., \& Higgins, C. (1995). Application of social cognitive theory to training for computer skills. Information Systems Research, 6(2), 118-143. http://dx.doi.org/10.1287/isre.6.2.118

Cropanzano, R., \& Mitchell, M.S. (2005). Social exchange theory: An interdisciplinary review. Journal of Management, 31, 874. http://dx.doi.org/10.1177/0149206305279602

Davis, F. D., Bagozzi, R. P., and Warshaw, P. R. (1992). User acceptance of computer technology: A comparison of two theoretical models. Management Science, 35(8), 982-1002.

Davis, F.D. (1986). A technology acceptance model for empirically testing new end-user information systems: Theory and results. MA: Sloan School of Management, Massachusetts Institute of Technology.

Deci, E., \& Ryan, R. (1985). Intrinsic motivation and self-determination in human behavior. New York: London: Plenum.

Fishbein, M., \& Ajzen, I. (1980). Understanding attitudes and predicting social behavior. Englewood Cliffs, NJ: Prentice-Hall.

Gallivan, M.J., Spitler, V.K., \& Koufaris, M. (2005). Does information technology training really matter? A social information processing analysis of coworkers' influence on IT usage in the workplace. Journal of Management Information Systems, 22(1), 153-192.

Géczy, P., Izumi, N., \& Hasida, K. (2011). Cloud services: Do risks outweigh benefits? 2011 2nd International Conference on Economics, Business and Management IPEDR, 22. 
Grance, T. (2010). The NIST cloud definition framework. NIST.

Hale, J. L., Householder, B.J., \& Greene, K.L. (2003). The theory of reasoned action. In J.P. Dillard \& M. Pfau (Eds.), The persuasion handbook: Developments in theory and practice (pp. 259 - 286). Thousand Oaks, CA: Sage.

Huang, E., \& Chuang, M.H. (2007). Extending the theory of planned behavior as a model to explain post-merger employee behavior of IS use. Computers in Human Behavior, 23(2007), 240-257. http://dx.doi.org/10.1016/j.chb.2004.10.010

Igbaria, M., Zinatelll, N., Cragg, P., \& Cavaye, A. (1996). Personal computing acceptance factors in small firms: a structural equation model, MIS Quarterly, 21.

Jackson, C.M., Chow, S., \& Leitch, R.A. (1997). Toward an understanding of the behavioral intention to use an information system. Decision Sciences, 28(2), 357-389.

Jeffrey, K., \& Neidecker-Lutz, B. (2009). The future of cloud computing: Opportunities for European cloud computing beyond 2010.

Jlelaty, M., \& Monzer, Y. (2012). Factors in cloud computing adoption. Lund University.

Karahanna, E., \& Straub, D. W. (1999). The psychological origins of perceived usefulness and ease of use. Information and Management, 35(4), 237-250.

Lee, Y., Kozar, K.A., \& Larsen, K.R.T. (2003). The technology acceptance model: Past, present and future. Communications of the AIS, 12(50), 752-780.

Legris, P., Ingham, J., \& Collerette, P. (2003). Why do people use information technology? A critical review of the technology acceptance model. Information \& Management, 40(3), 191-204. http://dx.doi.org/10.1016/S0378-7206(01)00143-4

Low, C., Chen, Y., \& Wu, M. (2011). Understanding the determinants of cloud computing adoption. Industrial Management \& Data Systems, 111(7), 1006-1023. http://dx.doi.org/10.1108/02635571111161262

Marston S., Li Z., Bandyopadhyay S., Juheng Z., \& Ghalasi, A. (2011). Cloud computing: The business Perspective. Decision Support Systems, 51, 176-189. http://dx.doi.org/10.1016/j.dss.2010.12.006

Mathieson, K. (1991). Predicting user intentions: comparing the technology acceptance model with the theory of planned behavior. Information Systems Research, 2(3), 173-191. http://dx.doi.org/10.1287/isre.2.3.173

McKendrick, J. (2011). Cloud bursts onto the enterprise mainstream. Database Trends and Applications, December, pp. 2-5.

Mell, P. \& Grance, T. (2009). The NIST definition of cloud computing version 15. National Institute of Standards and Technology.

Miller, M. (2008). Cloud computing: Web-based applications that change the way you work and collaborate. Queue Publishers. 
Plummer, D. C., Smith, D. M., et al. (2009). Five refining attributes of public and private cloud.

Rogers, E.M. (1995). Diffusion of innovations, fourth Ed. New York: Free Press.

Shimba, F. (2010). Cloud computing: Strategies for cloud computing adoption. Dublin: Dublin Institute of Technology.

Sriram, I., \& Khajeh-Hosseini, A. (2010). Research agenda in cloud technologies. Retrieved on 1/11.2012 from Http://arxiv.org/abs/1001.3259

Subramanian, G.H. (1994). A replication of perceived usefulness and perceived ease of use measurement. Decision Sciences, 25(5/6), 863-874.

Szajna, B. (1996). Empirical evaluation of the revised technology acceptance model. Management Science, 42(1), 85-92. http://dx.doi.org/10.1287/mnsc.42.1.85

Taylor, S., \& Todd, P. A. (1995). Understanding information technology usage: A test of competing models. Information Systems Research, 6, 144-176. http://dx.doi.org/10.1287/isre.6.2.144

Thibault, J. W., \& Kelley, H. H. (1952). The social psychology of groups. New York: John Wiley \& Sons.

Thompson, R. L., Higgins, C. A., Howell, J. M. (1991). Personal computing: Toward a conceptual model of utilization. MIS Quarterly, 15(1), 124-143. http://dx.doi.org/10.2307/249443

Triandis, H. C. (1977). Interpersonal behavior. Monterey, CA: Brooke/Cole.

Vallerand, R.J. (2001). A hierarchical model of intrinsic and extrinsic motivation in sport and exercise. In: G. Roberts [Eds.], Advances in motivation in sport and exercise [www], IL, Champaign: Human Kinetics, pp. 263-319.

Venkatesh, V. (1999). Creating favorable user perceptions: Exploring the role of intrinsic motivation. MIS Quarterly, 23(2), 39-260. http://dx.doi.org/10.2307/249753

Venkatesh, V. and Speier, C. (1999). Computer technology training in the workplace: A longitudinal investigation of the effect of the mood. Organizational Behavior and Human Decision Processes, 79(1), 1-28. http://dx.doi.org/10.1006/obhd.1999.2837

Venkatesh, V. and Speier, C., \& Morris, M. (2002) User acceptance in individual decision making about technology: Toward an integrated model. Decision Science, 33(2), 297-316. http://dx.doi.org/10.1111/j.1540-5915.2002.tb01646.x

Venkatesh, V., \& Davis, F. D. (2000). A theoretical extension of the technology acceptance model: four longitudinal field studies. Management Science, 46(2), 186-204. http://dx.doi.org/10.1287/mnsc.46.2.186.11926 


\section{Macrothink}

Journal of Management Research ISSN 1941-899X 2013, Vol. 5, No. 1

Venkatesh, V., \& Davis, F.D. (1996). A model of the antecedents of perceived ease of use: development and test. Decision Sciences, 27(3), 451-481. http://dx.doi.org/10.1111/j.1540-5915.1996.tb01822.x

Venkatesh, V., Morris, M.G., Davis, G.B., \& Davis, F.D. (2003). User acceptance of information technology: Toward a unified view. MIS Quarterly, 27(3), 425-478.

Voona, S., \& Venkantaratna, R. (2009). Cloud computing for banks. Infosys Technologies Ltd.

West, R., \& Turner, L. H. (2000). Introducing communication theory: Analysis and application. Mountain View, CA: Mayfield. 